\title{
International Public Sector Accounting Standards (IPSAS) Implementation and Financial Reporting: Issues and Challenges in South-East Nigeria
}

\author{
Sunny Biobele Beredugo \\ Arthur Jarvis University, Akpabuyo, Cross River State Nigeria \\ beredugosunny@gmail.com
}

\begin{abstract}
The main objective of the study was to identify the challenges of IPSAS implementation in the Nigerian Public Sector. This was as a result of low level of accountability and improper application of accounting standards by government institutions. A structured questionnaire was used to elicit information from the various respondents. The population of the study consists of accountants, auditors and cash officers in government ministries, departments and agencies in Abia, Anambra, Enugu, Ebonyi and Imo States. The population was estimated at 8901 for the five States. The sample size of 387 was drawn using the stratified sampling technique. The Analysis of Variance (ANOVA) was used for the hypothesis test. The results showed that the challenges that impinge the full implementation of IPSAS in Nigeria include: governments' unwillingness in terms of political-will towards full IPSAS implementation; statutory adjustment, inadequate funding and institutional commitment among others. It was therefore recommended that there should be adequate funding for the IPSAS implementation projects as most of the Public Sector Entities attributed inability to implement IPSAS Accrual to paucity of funds. Government should also show more political will as well as commitment and support for the accrual basis IPSAS implementation at the Local Government level.
\end{abstract}

Keywords: IPSAS, Political-Will, Expertise Availability, Institutional Commitment, Statutory Adjustment

How to Cite:

Beredugo. S. B. (2021). International Public Sector Accounting Standards (IPSAS) Implementation and Financial Reporting: Issues and Challenges in South-East Nigeria. Journal of Accounting and Taxation, 1(1). 1-11. DOI. https://doi.org/10.47747/jat.v1i1.405

\section{Introduction}

As the transparency and disclosure of financial information has increased between countries around the world, efforts are being made to increase public confidence in financial reporting. This is also intervened in the globalization resilience through international trades, investments and collaborations (Beredugo, Igbeng, \& Eze, 2013). The need to hold the government accountable for results is becoming more desirable. This makes the demand for quality 
financial reports imperative as financial reports remain the only means to communicate organisations' financial affairs to its stakeholders.

However, in recent times, even after the implementation of accrual-based IPSAS by some State Governments in Nigeria there still exists contention on the reliability of their financial reports. This could be as a result of the infrastructural gap regarding the need for skilled staff that could effectively translate the standards and should report on some specific areas, particularly in the narrative notes accompanying the financial statements to provide detail explanation of the financial data to the users. Another gap could be the need for a paradigm shift in finance culture and mindset to exploit the opportunities presented to drive value. Reports from some States in Nigeria shows audit qualifications on government's assets; income and receivables; uncommon and extravagant expenditure; and investment property. Technical accounting issues and challenges include valuation, depreciation, impairments and fair value of investment property, while the existing technology in some States does not equally support full IPSAS implementation (Izueke, Onah, Ugwuibe, Okwueze, Agu, Ugwu \& Ezeibe, 2020).

IPSAS is the focal point of the global government accounting revolution. It is the response to calls for more government accountability and financial transparency. On the other hand, comparability, reliability, and relevance of financial information are key issues in the IPSAS and it is here that significant changes with major implications for IPSAS takes place. IPSAS indeed poses homogenizing effect on the Nigerian public sector financial reporting system. These effects also revolve in the application of some unique standards that are completely alien to government financial reporting in Nigeria.

\subsection{Statement of the Problem}

The IPSAS accrual basis financial reporting framework is expected to be a successful tool to address government provision of financial information problem, but there still exist infrastructural gaps in the public sector that is required for the full IPSAS implementation. Financial reports had continued to witness a low level accountability and improper application of accounting standards by government institutions in the Nigerian Public Sector. In a study conducted by FAAC (2020), it was also alleged that some States that have implemented IPSAS do not fully comply with the reporting requirements.

Revamping institutional commitments and engaging in statutory adjustments toward IPSAS implementation have become important issues confronting the financial reporting quality in Nigerian Public sector (Babatunde, 2017). It is no doubt that some challenges were responsible for the nonconformity with the trend in globalization and when they are adequately addressed it would enhance full IPSAS implementation in Nigeria. It is the pervasive nature of IPSAS challenges that led to the following question begging for answer which include if there are differences in the opinion of accountants, auditors, cash officers on the challenges of IPSAS implementation in the Nigerian Public Sector?

\section{Literature Review}

There is a broad agreement that as a matter of corporate policy, every organization be it government or private entities should strive to be committed in a manner that is ethically transparent through effective financial reporting (Ebitu \& Beredugo, 2015). Financial 
statements of governments are expected to be fashioned after the standards established by the IPSASB.

The acceptance of IPSAS by government entities is driven by the need to increase efficiency, accountability, and expertise in public resource management (Aggestam, 2010). This is also underpinned on the agency theory wherein the agency cost can be reduced by educating government officials and others privy to the financial statement and by disclosing more information in the financial statement in order to enhance more transparency, and effective use of government resources in the right direction. By implication, stakeholders expect cumulative income to be used in an appropriate, practical and well-thought-out manner, in line with strategic management ideals. In view of this government should give stewardship of its affairs through acceptable standards (Igbeng, Beredugo \& Adu, 2015).

Accrual based IPSAS incorporates relevant standards basically to make decisions through extensive asset and liability reporting and enhanced financial management by providing an overview of a company's overall financial position by providing an immediate comparison between accounting periods while improving strategic planning (Aggestam, 2010). This hybrid level of measurement and disclosure is also used in informing interested publics on government activities.

Accrual IPSAS improves the ability to provide accurate information on resources, debt and income, thereby improving communication with a variety of stakeholders (Wong, 1998). Accrual accounting also improves the ability to obtain comprehensive cost information. This is a key factor in improving an organization's planning, governance, and accountability (Chan, 2003). The Accrual based IPSAS was advocated because of the failure in the cash basis accounting system of the public sector. The Accrual based accounting recognizes both cash and non-cash transactions reflecting the true cost of an entity's operations. This was not the case for cash accounting (Biraud, 2012).

Accrual based IPSAS has made some changes to the accounting methods for assets, mostly long-term assets. It brings about the full disclosure of all assets and liabilities irrespective of when payment is made (Diamond, 2002). Robinson (2008) found that IPSAS also ensure that assets are carried at their recoverable costs and proper treatment of depreciation and some of the cost of capital are adequately treated to improve the conceptualization.

\subsection{Challenges of IPSAS Implementation in the Nigerian Public Sector}

Although the Nigeria Government at the federal level has fully accepted IPSAS since January 2016 (Ugwumadu, 2015), each of the 36 States in Nigeria has its distinct implementation period. With respect to the Financial Reporting Commission (FRC) Act of 2011, the FRC is incharge for establishing IPSAS-compliant framework. The FRC has developed a roadmap for the phased acceptance and implementation of IPSAS at all levels of the Federal Government of Nigeria. The FRC says it hopes IPSAS will help attract foreign investment, improve financial management, transparency, accountability and combat corruption. Nigeria is working to improve financial reporting and accountability, but we need to do more from a best practice perspective. Some government agencies have not relocated to IPSAS as needed (Premium Times, 2016). 
The Nigerian Accountant General acknowledged that the country needs to develop its accounting capacity to meet the requirements for implementing IPSAS. Akhidime, (2012) concluded that the quality and accountability of financial reporting in the public sector of Nigeria leaves room for improvement. There are also ongoing challenges with the internal audit function of some entities.

Most States have partially adopted the accrual-based IPSAS, but are waiting for the completion of certain financial management information system projects that support full implementation. Some states use the built-in IPSAS but it is not fully in compliance with actual IPSAS requirements due to legal adjustments. The quality of accounting in Nigeria's public sector remains a serious problem, although the number and number of ratings has declined. The main reason for qualified, unfavorable and negative opinions is the inadequate or lack of documentation of the amounts disclosed in the financial statements (FAAC, 2020).

In particular, infrastructure assets, revenue and accounts receivable have been identified as problem areas. Examples of some local government review paragraphs that received rated audit opinions suggest that qualifications are mainly associated with financial management instead of financial reporting standards (Akinleye \& Alaran-Ajewole, 2018). A common area of qualification is related to long-term assets. Income and accounts receivable; regulation; irregular and extravagant spending and investment in real estate. Common evaluation issues include misrepresentations due to lack of support documentation and inconsistent display of documentation. Technical accounting challenges are associated with impairment, accounting for fair value of assets, other valuation and staff challenges (Onuba, 2018).

Indeed, the Nigerian public sector faces a number of challenges in implementing IPSAS. Some of them are associated with certain accounting issues, such as incomplete and inaccurate records that are not available to determine opening balances and valuation issues for certain types of assets and complex financial instruments (Akinleye \& Alaran-Ajewole, 2018). But there were also broader issues. Ability issues that lead to excessive reliance on donor funding and consultants, talent and skills issues with a lack of appropriate IPSAS skills. There is also the issue of accounting and budget integration. As a result, both frameworks are compatible and government can be held accountable for how they use their allocated resources. Specifically, the challenges of implementing IPSAS in Nigeria are listed under the following headings:

\subsubsection{Political-will to implement IPSAS}

The level of knowledge and understanding of the IPSAS framework, as well as the level of stakeholder involvement in its adoption, varies considerably from State to State. Public institutions, ministries, legislators, politicians, and the general public are accustomed to the principles of cash accounting (Akhidime, 2012). Successful adoption of IPSAS requires the understanding, education and participation of key stakeholders such as politicians, auditors, accountants, state-owned banks and ministries. This is difficult and government executives need to participate in auditing and financing functions with the public accounting committee (or equivalent) to support the process. If the change is introduced, the change will not succeed. Political will of implementation is required and a "champion" is necessary for IPSAS to gain momentum. Similarly, IPSAS approval requires successful internal participation. We need 
cross-functional support, a strong partnership between finance and auditing. Support for auditing capabilities is especially important (Harjowiryono, 2016).

\subsubsection{Cost of implementation}

Nigeria has decided to adopt IPSAS for all government agencies on the same day as International Financial Reporting Standards. Therefore, resources were insufficient and the initial consultation cost was high. Implementation costs (finance and resources) are underestimated from a financial and auditing perspective. The implementation cost was enormous. This includes training, the use of specialized external consultants, IT updates, and the cost of developing appropriate translation and guidance tools. All Nigerian states have adopted IPSAS in conjunction with a broader financial management improvement program that requires additional investment (FAAC, 2020).

Existing technologies do not necessarily support implementation. It is expensive and requires expert advice and consultation to support setup, replace existing IT systems, data structures, and spreadsheets. The reporting system and structure need to be updated as part of the migration process.

\subsubsection{Expertise availability}

The need to train staff on the standards and systems used was greater than expected, and the public sector lacked relevant knowledge and skills, requiring manuals to be developed. As a result, most Accountant General Offices across the country lack competence, experience and skills, and as a result, offices do not regulate accounting policies or guidelines.

FAAC (2020) also identified that the accounting of some States that implemented IPSAS was not fully compliant with IPSAS. That is, government guarantees and debt are undervalued. Resources and liabilities are not properly accounted for. Pension debt is not considered. Managing the change process, such as accepting staff and stakeholders and developing effective communication strategies, was difficult. Human resources were needed to support the deployment of computerized growth-based systems. Fixed asset accounting was a particular challenge, as fixed asset records were not retained in older cash accounting systems (Alleyne, 2014).

Ministries and government agencies lack the required skills, competencies and staff levels. IPSAS implementation requires training, hiring and retention of qualified staff with IPSAS proficiency. Other technical challenges to overcome are the lack of knowledge and understanding of IPSAS. Other topics include translation of values and manuals (Onuba, 2018).

The skills gaps described in this study include a wide range of information areas, primarily the descriptive information that follows financial statements to explain what financial data tells users. IPSAS implementation requires not only a radical shift in skills, but also change in financial culture and ideas to gain access to the resources professionals provide to generate profit. In addition to the required skills, there must be balance between the internal and external resources. Caution should be taken with consultants, ensuring that appropriate knowledge is transferred to long-term indoor staff. Long implementation deadlines mean that staff is not always involved, so entities need to consider ways to maintain organizational memory and retain implicit organizational knowledge throughout the process. Means Implementation also requires new business models and spreadsheets (Onuba, 2018). 


\subsubsection{Statutory adjustment}

The challenge of structural reforms to address the implementation of IPSAS is a major challenge. Legal amendments, new regulations and government practices are needed. It is complex, time consuming, and varies from State to State. Government standards bodies and funding committees must take responsibility for reviewing and reflecting country-specific interpretations and applications. Most States have chosen to introduce advanced cash standards as a useful milestone for the full implementation of IPSAS. The implementation plan does not fully reflect the constitutional, national, state and local conditions. Other issues include lack of project management and defined milestones, lack of legislative framework to implement IPSAS, and lack of resources and investment in processes.

Some States that have begun implementing accrual IPSAS, have witnessed deviations from IPSAS requirements to comply with the statutory / legislative requirements of financial reporting; although, for them, such a difference does not mean a difference that goes against the purpose of the financial statement listed in IPSAS as described in paragraph 31 of IPSAS 1. However, it is clear that such a difference is necessary and, as such, the Government cannot claim to comply with IPSAS. Therefore, structural and legal changes are needed. Government regulatory frameworks strengthen the need to change the environment of information systems to support IPSAS integration and disclosure requirements, the technical challenges of integrating State entities implementing IPSAS, and staff capacity in application of IPSAS (Onuba, 2018).

\subsubsection{Institutional commitment}

The issue of compromise from most Nigerian state governments further paralyzed the full implementation of IPSAS. Nigeria began implementing accrual-based IPSAS in 2016, and since then some lessons have been learned and challenges have been identified. From the process to the present, most government accounting contains errors, some of which were years old. We needed policies to address these errors in the past and the new technology needed by ministries to revise their accounts. The integrated financial system failed to comply with the detailed spreadsheets required to implement IPSAS. IPSAS based computer information system is required. In most cases, State governments have adopted standards consistent with cash-based IPSAS without announcing their commitment to adopt IPSAS on an accrual basis (FAAC, 2020).

\section{Research Method}

\subsection{Research Design}

The survey research design was used to investigate the Challenges of IPSAS Implementation in the South East of the Nigerian Public Sector. This is undertaken by administering a questionnaire to accountants, auditors and cash officers in government's ministries, departments and agencies. 


\subsection{Population and Sample size determination}

The accessible population of the study comprises staff of all accounting departments of various ministries and local government areas, in the five South-East States, in Nigeria. This population consists of professional accountants and auditors in Anambra State, Abia State, Enugu State, and Imo State. The population was 8901 for the five states, while the sample size used was 397 after the application of the Yamane (1967) sample size determination techniques. The stratified sampling was used to ascertain the respective respondents from the 5 states. The collected data were tested for reliability using the Cronbach alpha and a reliability result of 0.7721 was arrived at indicating that the instrument was reliable.

\subsection{Method of Hypothesis Testing}

The Analysis of Variance (ANOVA) was applied to test the hypothesis stated in a null $\left(\mathrm{H}_{0}\right)$ form that there are no significant challenges of IPSAS implementation in the Nigerian Public Sector.

\section{Finding and Discussions}

\subsection{Data presentation and Analysis}

Table 1 contains information on items 1 to 5 . This information is on factors affecting IPSAS implementation. Items 1 reveal that $5(1.3 \%)$ and $50(12.9 \%)$ respondents respectively were undecided and strongly disagree that Political-will is a factor affecting IPSAS implementation, 103 (26.6\%) respondents, on one hand, disagreed, $150(38.8 \%)$ agreed while $79(20.4 \%)$. Item 2 shows that $9(2.3 \%)$ respondents were undecided that cost of implementation is factor affecting IPSAS implementation. It was discovered that $72(18.6 \%)$ respondents strongly disagreed to the assertion, 73 (18.9\%) disagreed, $163(42.1 \%)$ agreed; while $70(18.1 \%)$ strongly disagreed

Table 1: Distribution of Responses on factors affecting IPSAS implementation

\begin{tabular}{lllllll}
\hline $\begin{array}{l}\text { Component of factors affecting } \\
\text { IPSAS implementation: }\end{array}$ & $\mathbf{U}$ & SD & D & A & SA & Total \\
\hline 1) Political will towards & 5 & 50 & 103 & 150 & 79 & 387 \\
IPSAS implementation & $1.3 \%$ & $12.9 \%$ & $26.6 \%$ & $38.8 \%$ & $20.4 \%$ & $100 \%$ \\
2) Cost of implementation & 9 & 72 & 73 & 163 & 70 & 387 \\
& $2.3 \%$ & $18.6 \%$ & $18.9 \%$ & $42.1 \%$ & $18.1 \%$ & $100 \%$ \\
3) Availability of expertise & 4 & 49 & 115 & 171 & 48 & 387 \\
& $1.0 \%$ & $12.7 \%$ & $29.7 \%$ & $44.2 \%$ & $12.4 \%$ & $100 \%$ \\
4) Statutory adjustment & 8 & 38 & 84 & 112 & 145 & 387 \\
& $2.1 \%$ & $9.8 \%$ & $21.7 \%$ & $28.9 \%$ & $37.5 \%$ & $100 \%$ \\
5) Institutional commitment & 21 & 33 & 115 & 131 & 87 & 387 \\
& $5.4 \%$ & $8.5 \%$ & $29.7 \%$ & $33.9 \%$ & $22.5 \%$ & $100 \%$
\end{tabular}

Source: Field Survey, 2021 
Item 3 shows that $4(1.0 \%)$ respondents were undecided that the availability of expertise was a factor that affects IPSAS implementation, $49(12.7 \%)$ respondents on the other hand strongly disagreed with the assertion, $115(29.7 \%)$ respondents disagreed, 171(44.2\%) agreed, while 48 (12.4\%) strongly disagreed. item 4 also shows that $8(2.1 \%)$ and $38(9.8 \%)$ respondents were undecided and strongly disagreed respectively that statutory adjustment is a factor affecting IPSAS implementation. $84(21.7 \%)$ respondents disagreed, 112 (28.9\%) respondents agreed, while $145(37.5 \%)$ respondents strongly agreed. item 5 reveals that $21(5.4 \%)$ respondents were undecided while $33(8.5 \%)$ respondents strongly disagreed that institutional commitment is a factor affecting IPSAS implementation; 115 (29.7\%) respondents on the other hand disagreed; 131(33.9\%) agreed, while 87 (22.5\%) strongly agreed.

\subsection{Test of Hypothesis}

Table $2 \mathrm{a}, \mathrm{b}$ shows the result of the Analysis of variance of the opinion of Accountants, Auditor and cash officers on the challenges of IPSAS implementation in the Nigerian Public sector.

Table 2 a. Group Statistics

IPSAS challenges

\begin{tabular}{|l|l|l|l|}
\hline Designation & Mean & $\mathrm{N}$ & Std. Deviation \\
\hline Accountants & 16.4818 & 137 & 6.46836 \\
Auditors & 17.0093 & 108 & 6.15151 \\
Cash officers & 16.8873 & 142 & 6.37270 \\
Total & 16.7778 & 387 & 6.33374 \\
\hline
\end{tabular}

Source: Field Survey, 2021

Table 2 b

ANOVA Table

\begin{tabular}{|c|c|c|c|c|c|c|c|}
\hline & & & $\begin{array}{ll}\text { Sum } & 0 \\
\text { Squares }\end{array}$ & Df & $\begin{array}{l}\text { Mean } \\
\text { Square }\end{array}$ & $\mathrm{F}$ & Sig. \\
\hline \multirow{5}{*}{\begin{tabular}{|l} 
IPSAS \\
Challenge \\
Designation
\end{tabular}} & \multirow{3}{*}{$\begin{array}{l}\text { Between } \\
*^{*} \text { Groups } \\
\end{array}$} & (Combined) & 19.497 & 2 & 9.748 & .242 & .785 \\
\hline & & Linearity & 11.287 & 1 & 11.287 & .280 & .597 \\
\hline & & $\begin{array}{l}\text { Deviation } \\
\text { Linearity }\end{array}$ & 8.209 & 1 & 8.209 & .204 & .652 \\
\hline & \multicolumn{2}{|c|}{ Within Groups } & 15465.392 & 384 & 40.274 & & \\
\hline & \multicolumn{2}{|l|}{ Total } & 15484.889 & 386 & & & \\
\hline
\end{tabular}

Source: Field Survey, 2021

The result from the $\mathrm{f}$-statistics shows that there is no significant difference in the perception of the respondents on the challenges of IPSAS in the Nigeria public sector. This was further evidence in the mean and standard deviation which shows accountant had $(\mathrm{M}=16.4818$, $\mathrm{SD}=6.46836)$, Auditors $(\mathrm{M}=17.0093, \mathrm{SD}=6.1515)$ and Cash Officers $(\mathrm{M}=16.8873$, $\mathrm{SD}=6.3337)$. $\mathrm{f}(384)=.242, \mathrm{p}=.785$. The magnitude of the differences in the means was equally insignificant (eta squared $=0.001$ ). 
$\mathrm{H}_{0}: \quad$ There is no significant difference in the opinion of accountants, auditors, cash officers on the challenges of IPSAS implementation in the Nigerian Public Sector.

The result from the $\mathrm{F}$ - statistics shows that there is no significant difference in the perception of the respondents on the challenges of IPSAS in the Nigeria public sector. This was further evidence in the mean and standard deviation which shows that accountant had $(\mathrm{M}=16.4818$, $\mathrm{SD}=6.46836)$, Auditors $(\mathrm{M}=17.0093, \mathrm{SD}=6.1515)$ and Cash Officers $(\mathrm{M}=16.8873$, $\mathrm{SD}=6.3337)$. $\mathrm{f}(384)=.242, \mathrm{p}=.785$. The magnitude of the differences in the means was equally insignificant (eta squared $=0.001$ ). $\mathrm{H}_{\mathrm{o}}$ is retained and $\mathrm{H}_{1}$ is rejected.

Thus, there are no significant differences in the opinion of accountants, auditors, cash officers on the challenges of IPSAS implementation in the Nigerian Public Sector.

\section{Summary}

Result from the hypothesis shows that there are no significant differences in the perception of respondents (accountants, auditors, cash officers) on the challenges of IPSAS implementation in the Nigerian Public Sector. The challenges discovered are political will toward IPSAS implementation, cost of implementation, availability of expertise, statutory adjustment and institutional commitment. Evidently all respondents from the five States collectively agreed that key stakeholders such as political office holders are showing little enthusiasm in the implementation of accrual based IPSAS for some obvious reasons. The respondents were also of the opinion that the huge cost of implementation such as: costs of training, the use of specialized external consultants, IT upgrades and the development of appropriate guidance and translation tools have continued to impede full accrual based IPSAS implementation. Another important challenge was the need for expertise to supports accrual based accounting technology which is deficient in the wake of IPSAS implementation. There is also a need for structural reform to accommodate accrual based IPSAS requirement while there is little or no commitment in ensuring that accrual-based IPSAS is implemented in the required time-frame.

Governments' unwillingness in terms of political-will towards full IPSAS implementation, statutory adjustment as well as institutional commitment among others have continued to truncate the efficacy attached to IPSAS implementation drive in Nigeria.

There should be adequate funding for the IPSAS implementation projects as most of the Public Sector Entities attributed inability to implement IPSAS Accrual to paucity of funds. Government should also show more political will as well as commitment and support for the accrual basis IPSAS implementation at the Local Government level. There should be efforts to intensify the three tiers of government towards the passage of enabling laws and Public Finance Management Legislation.

\section{References}

Aggestam, C. (2010). A project management perspective on the adoption of accrual based IPSAS, Copenhagen Business School, 11- 14. 
Akhidime, A.E. (2012). Accountability and Financial Reporting in Nigeria Public Financial Management: An Empirical Exploration. Knowledge Review, 26 (3): 36-44.

Akinleye, G. T and Alaran-Ajewole, A. P. (2018). Effect of International Public Sector Accounting Standards (IPSASs) on information delivery and quality in Nigeria. Research Journal of Finance and Accounting, 9(6): 147-163.

Alleyne, P. (2014), Developments in Public Sector Accounting Practices in Barbados, University of the West Indies. Retrieved from <https://www.researchgate.net/ publication/268150092_Developments_in_Public_Sector_Accounting_Practices_in_Ba rbados>, accessed 23 October 2017.

Babatunde, S. A. (2017). Implementing International Public Sector Accounting Standards in Nigeria: Issues and challenges. International Journal of Business, Economics and Law, 12 (1): 52- 60.

Beredugo, S. B., Igbeng, E. I. \& Eze, F. J. (2013). The Significance of International Corporate Governance Disclosures on Financial Reporting in Nigeria, International Journal of Business and Management. 8(8), 100-108.

Biraud, G. (2012). Preparedness of United Nations system organization for the IPSAS. Geneva, Joint Inspection Unit, 20p.

Chan, J. L. (2003). Government accounting, an assessment of theory, purpose and standards: Public Money and Management, 1(3): 13-20.

Diamond, J. (2002). Performance budgeting - Is accrual accounting required, Washington D.C.: International Monetary Fund, Working Paper, no. 02/240, 23p.

Ebitu, E. T. \& Beredugo, S. B. (2015). Business Ethics and the Performance of Service Firms in Calabar, Cross River State, Nigeria. European Journal of Hospitality and Tourism Research, 3 (2), 28-38.

FAAC (2020). FAAC Sub-committee on international public Sector Accounting Standards (IPSAS) Implementation in Nigeria: Report on the monitoring and evaluation of the level of implementation of IPSAS Accrual basis of Accounting by Public Sector Entities (PSEs) in Nigeria. Federal Ministry of Finance, Budget and National Planning, 34p.

Harjowiryono M. (2016). Presentation: Improving Public Sector Management; Public Financial Management Retrospective Study - Indonesian Experience, 65p.

Igbeng, E. I., Beredugo, S. B. \& Adu, V. A. (2015). Evaluation of Public Accountability and Tax Culture among Tax Payers in Nigeria. International Journal of Management Science and Business Administration, 1(9), 7 - 13

Izueke, E., Onah, F., Ugwuibe, C. O., Okwueze, F., Agu, S., Ugwu, C., \& Ezeibe, C. (2020). Implementation of International Public Sector Accounting Standards and Transparency and Accountability in the Public Sector. International Journal of Finance and Accounting, 9(3): 67-76

Onuba, I. (2018, April 2018). FG to address IPSAS adoption challenges. Punch Newspaper. Retrieved from https://punchng.com/fg-to-address-ipsas-adoption-challenges/ 32p, accessed 15,2019 
Premium Times (2016). Nigeria Audits 33 Agencies, uncovers N450 billion unremitted revenue. Retrieved from https://www.premiumtimesng.com/ news/headlines/216854nigeria-audits-33-agencies-uncovers-n450-billionunremitted- revenue.html, accessed 23 October 2017.

Robinson, T. W. (2008). Correcting accounting for deferred revenue, The Tax Adviser, 124p. Retrieved from https://www.thetaxadviser.com/issues/2008/nov/correctingaeveml. 23 p, accessed 18 March, 2018

Ugwumadu, J. (2015). Argentina default 'highlights need for IPSAS. Public Finance International, 98p. Retrieved from http://www. publicfinanceinternational.org/news /2014/08/argentina-default-\%E2\%80\%98highlights-need-ipsas\%E2\%80\%99, accessed 23 October 2017.

Wong, S. (1998). Full speed ahead - how to move forward full accrual accounting for capital assets, CMA Magazine, (October, 1998): 1-8.

\section{Copyrights}

Copyright for this article is retained by the author(s), with first publication rights granted to the journal.

This is an open-access article distributed under the terms and conditions of the Creative Commons Attribution license (http://creativecommons.org/licenses/by/4.0/) 